\title{
Integro-differential equation with two times modifications
}

\section{VERONICA-ANA ILEA and DiAnA OTROCOL}

\section{ABSTRACT.}

We consider an integro-differential equation with two times modifications. Existence, uniqueness and monotony results of solution for the Cauchy problem are obtained using weakly Picard operator theory. In the last section we present a step method for this type of equation.

"BABEŞ-BOLYAI" UNIVERSITY

DEPARTMENT OF APPLiEd MATHEMATICS

KOGĂLNicEANU 1, CluJ-NAPOCA, ROMANIA

E-mail address: vdarzu@math.ubbcluj.ro

T. Popoviciu Institute of Numerical ANAlysis

ROMANIAN ACADEMY

ClUJ-NAPOCA, ROMANIA

E-mail address: dotrocoleictp.acad.ro 